\title{
David Oliver: Treating NHS staff fairly when things go wrong
}

\section{David Oliver consultant in geriatrics and acute general medicine}

Berkshire

In some recent high profile NHS scandals patients and their families have been failed horribly - think Mid Staffs, ${ }^{1}$ Morecambe Bay, ${ }^{2}$ and Southern Health. ${ }^{3}$ Hurt can be compounded by complacent, obfuscatory responses to complaints. ${ }^{4}$

It can be hard to defend the reputation of NHS staff amid justifiable anger. You can't redress wrongs for one group by wronging another, but rebalancing the perspective can bring accusations of insensitivity.

The NHS constitution sets out rights for employees and patients. ${ }^{5}$ Simplistic narratives focusing on individual accountability aren't always fair to staff, and it shouldn't be taboo to say so.

Practitioners' and managers' lack of accountability often features in heated discussions about health services. Definitions of "accountability" encompass being responsible for your actions, giving satisfactory reasons for them, and disclosing information readily. ${ }^{67}$

I'd say that senior NHS executives are hugely accountable for their organisation's performance. Their work is high profile, in a business where people using the services are often emotionally distressed, and it is subject to constant media and regulatory scrutiny and political interference. Underfunding, rising demand, and workforce gaps add to the pressure. Tenure in such roles is often short. Vacant posts are hard to fill. ${ }^{8}$

Frontline clinicians are also accountable for their practice, requiring serial qualifications, mandatory training, revalidation, and continuing professional development. Registration means that regulators can investigate, prevent, or restrict practice. A new statutory duty of candour exists. ${ }^{9}$ Negligence law applies-sometimes criminal. ${ }^{10}{ }^{11}$ And staff who commit criminal offences are as accountable as any citizen, with extra consequences for their registration.

Simplistic narratives focusing on individual accountability aren't always fair to staff, and it shouldn't be taboo to say so

Nonetheless, complaint handling in the NHS can leave much to be desired. ${ }^{4}$ Prompt, transparent, rigorous investigation should be fair to all parties. Some allegations are demonstrably false or unfair, or they rest on misunderstandings rather than substandard care. A response to a complaint that doesn't unconditionally accept and apologise for every allegation, or which sometimes argues back, isn't necessarily a cover-up or a sham.

Adverse incidents and failures in care can create "second victims" of staff experiencing guilt, loss of confidence, or threats to their career. ${ }^{12}$ They may not be able to respond to media or online slander without breaching patient confidentiality or employer protocol.

Although some errors are clearly down to individual incompetence or poor behaviour, wider system factors may be to blame, such as staffing gaps, poor supervision, or unmanageable workload. Saying so is not an excuse. But fair treatment fosters good workforce morale and wellbeing and an open, "no blame" culture for reporting incidents, which helps to improve patient safety. ${ }^{13}$

Despite a febrile atmosphere around failings in healthcare, a fair discussion shouldn't mean ignoring the problems identified. An excessive focus on individual blame won't deliver the constructive solutions we need to improve care.

Competing interests: See www.bmj.com/about-bmj/freelancecontributors/david-oliver.

Provenance and peer review: Commissioned; not externally peer reviewed.

\footnotetext{
King's Fund. The Francis inquiry report. 17 Aug 2016. www.kingsfund.org.uk/projects/ francis-inquiry-report?gclid=CIGkp_2Ais8CFeoKOwod_YwCOA.

2 Kirkup B. The report of the Morecambe Bay investigation. Mar 2015. Department of Health. https://www.gov.uk/government/uploads/system/uploads/attachment_data/file/408480/ 47487_MBI_Accessible_v0.1.pdf.

3 Mazars. Independent review of deaths of people with a learning disability or mental health problem in contact with Southern Health NHS Foundation Trust April 2011 to March 2015. Dec 2015. https://www.england.nhs.uk/south/wp-content/uploads/sites/6/2015/12/mazarsrep.pdf.

4 Parliamentary and Health Service Ombudsman. Listening and learning: the ombudsman's review of complaint handling by the NHS in England 2010-11. 17 Oct 2011. www. ombudsman.org.uk/ data/assets/pdf file/0019/12286/Listening-and-Learning-Screen. pdf.
} 
5 NHS. The NHS constitution for England. 27 Jul 2015. https://www.gov.uk/government uploads/system/uploads/attachment_data/file/480482/NHS_Constitution_WEB.pdf.

6 Business Dictionary. Accountability (definition). www.businessdictionary.com/definition/ accountability.html.

7 Cambridge Dictionary. Accountable (definition). http://dictionary.cambridge.org/dictionary/ english/accountable.

8 King's Fund. Culture and leadership in the NHS: the King's Fund 2014 survey. May 2014. www.kingsfund.org.uk/sites/files/kf/field/field_publication_file/survey-culture-leadershipnhs-may2014.pdf.

9 Oliver D. The hardest word: managers and leaders should say sorry too. $B M$ 2015;351:h3644. doi:10.1136/bmj.h3644 pmid:26141688.

10 Medical Protection Society. Medicine and manslaughter. May 2014. www. medicalprotection.org/uk/casebook-and-resources/casebook-may-2014/medicine-andmanslaughter.
11 Daily Telegraph. Optometrist convicted of boy's manslaughter after missing "obvious" signs of lethal fluid build-up. 15 Jul 2016 www.telegraph.co.uk/news/2016/07/15 optometrist-convicted-of-boys-manslaughter-after-missing-obvious/.

12 Scott S. The second victim phenomenon: a harsh reality of healthcare professions. May 2011. https://psnet.ahrq.gov/perspectives/perspective/102.

13 NHS England. A promise to learn-a commitment to act. Aug 2013. https://www.gov.uk government/uploads/system/uploads/attachment_data/file/226703/Berwick_Report.pdf.

Published by the BMJ Publishing Group Limited. For permission to use (where not already granted under a licence) please go to http://group.bmj.com/group/rights-licensing/ permissions 